トピックス 新進気鋭 シリーズ
第53回 日本生物物理学会年会 若手招待講演

\section{ナノスケールの形状·化学物質濃度プロファイル を可視化するナノ電気化学顕微鏡の創生}

高橋康史 金沢大学理工研究域電子情報学系

\section{1. 微小電流を利用した化学物質の電流イメージング}

細胞表面の化学物質の濃度は時々刻々と変化してお り, 細胞の機能を理解するらえで，この変化を捉える 計測手法の開発が不可欠である. Wightman 教授は, 神経細胞などが放出するカテコールアミンを微小電極 で酸化還元し，その電流を計測する手法を確立し，現 在In vivoの計測に利用している. この手法は， ms オーダーの高い時間分解能を有しており，電極が微小 なため，組織上に電極を配置して計測を行らことが可 能であるが，手動のマニュピレータを利用するため位 置と化学物質の計測データの関係性が曖昧であった.

これに対して，1989年にテキサス大学の Bard 教授に より開発された走査型電気化学顕微鏡（SECM）は, ステッピングモータやピエゾステージを利用して，マ イク口電極を走査しながら酸化還元電流を検出する. 生体試料の SECM の研究は, 東北大学の末永智一教 授が，1990 年代前半から研究を行い，これまで細胞 膜の透過性 ${ }^{1)}$ や，呼吸量 ${ }^{2}$ の定量評価に利用してい る. 計測可能な化学物質は, 酸素や過酸化水素など電 極で酸化・還元が可能なものや，グルタミン酸なぞ酵 素反応を利用して検出するものが挙げられる。

SECM は，溶液中で拡散している化学物質を計測す るため，試料の凹凸の影響を受けやすい，そのため， プローブー試料間の距離制御が必要となる。 また，解 像度がマイクロ電極の半径に依存するため, 電極の微 細化も求められている，著者は，修士課程から一貫し てSECM の開発に携わって拈り，解像度の向上を目 指して，電極の微細化と，電極と試料との位置制御シ ステムの開発を行ってきた。この中で，位置制御シス テムとして取り入れた走査型イオンコンダクタンス顕 微鏡（SICM）に関して，次の項目で紹介する.

2.|ナノピペットを利用した非接触な

$$
\text { 形状イメージング }
$$

電極-試料間の距離制御は，試料の凹凸による形状
への影響を排除するだけでなく，電極を細胞に近接さ せることで，放出される化学物質を効率的に捉えるこ とや，各測定点で得られる高さ情報から，形状イメ一 ジを同時に取得できるといらメリットもある。そのた め，SECM に単一細胞の形状イメージング技術を融合 させることで, 高解像度の SECM イメージを形状イ メージと共に取得できる。

生細胞の細胞表面形状の計測に特化した技術とし て，SICMが挙げられる。SICMは，ナノピペットを 走査型プローブ顕微鏡の探針に利用し，イオン電流を 利用してピペットの位置を制御する。インペリアルカ レッジロンドンの Korchev 教授が，SICMを利用した 生細胞の形状測定を活発に行っている. SICM では, 非侵襲的に細胞の形状イメージングを行うことや，ピ ペットを利用して局所的に化学物質を放出することが 可能である. これまでの水平方向の分解能は, $3 \mathrm{~nm}$ ほどの報告がある ${ }^{3)}$ ．さらに，プローブを動かす制御 アルゴリズムの改良により，凹凸が他の細胞よりも著 しい神経細胞などの全体をイメージング可能となっ た ${ }^{4)}$ 。また，パッチクランプ5)，共焦点顕微鏡(6)との ハイブリットシステムや，高速システム ${ }^{7)}$ が開発され ている，著者は，このSICM とSECM の融合技術で あるナノ電気化学顕微鏡の開発に 2008 年から取り組 み，2010 年からは海外特別研究員として Korchev 教授 のもとで開発を行い, 生細胞表面の形状と化学物質の 同時イメージングを行った.

\section{3.| ナノ電気化学顕微鏡の開発と PC12 の}

SECM のマイクロ電極と, SICM のナノピペットの 二つの機能を有するプローブとして，リング型 ${ }^{8)}$ と $\theta$ 型9)を開発した。 ここでは， $\theta$ 型のプローブに関して 紹介する．先鋭化した $\theta$ 形状のクオーツガラスの片方 のバレルに，ブタンガスを導入した状態で先端部を加 熱することで，焼成カーボン層を形成し，このカーボ ン部分を電極として使用した。この手法は，特別な装

Development of Nano Electrochemical Microscopy for Visualizing Nanoscale Cell Surface Topography and Chemical Profile Yasufumi TAKAHASHI

Division of Electrical Engineering and Computer Science, Kanazawa University 

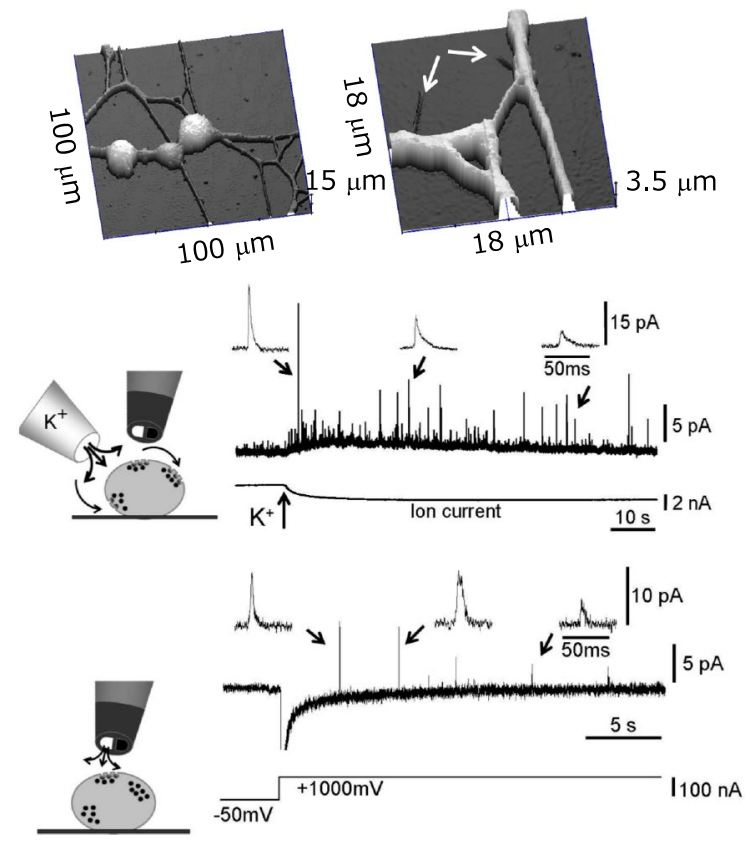

図 1

ナノ電気化学顕微鏡を利用したPC12 の形状イメージング. $100 \mathrm{~nm}$ ほどの Varicosity を可視化することができた．また，神経 伝達物質の計測では, カーボン電極に $+650 \mathrm{mV} v \mathrm{vs} . \mathrm{Ag} / \mathrm{AgCl}$ の電 圧を印加して，放出される神経伝達物質を酸化して，その電流応 答を経時的にとらえた． 細胞全体をもう一本のピペットで刺激し た場合と，ナノピペットで刺激した場合で放出頻度に違いがみら れた.

置を必要とせず，また，電極の作製が非常に簡便であ る.この $\theta$ 型プローブを用いて, 神経伝達物質の単一 細胞レベルでの計測を行った. プローブのサイズが $100 \mathrm{~nm}$ 泀どであり, 光学顕微鏡の分解能を上回る解 像度で神経細胞の形状イメージを非標識で取得できた (図 1).さらに，ナノ電気化学顕微鏡では，化学物質 の局所的なインジェクションにも利用できる. 実際に, 局所的に PC12（ラット副腎褐色細胞腫）を刺激する ため, SICMのバレルに $1.0 \mathrm{M} の \mathrm{~K}^{+}$を充填し，SICM のバレル側に電圧を印加して，細胞への化学的な刺激 を行った，すると，刺激によりカテコールアミンの放 出が誘導され，個々のベシクルの放出に対応したスパ イク状の電流シグナルを計測することができた。 た，細胞全体を刺激する従来法と較べ，スパイク状の 電流シグナルの応答頻度が非常に少ないことから，局 所的にカテコールアミンの放出を誘導できていること がわかる（図 1)。このように，ナノ電気化学顕微鏡 を用いることで従来の単一細胞レベルで評価されてい た現象を，細胞の局所で計測できるようになった。

\section{4. おわりに}

ナノ電気化学顕微鏡は, 生細胞の局所的な化学物質 の濃度変化や酵素の代謝や反応性の理解に広く資する と期待できる。その一方で，数十 $\mathrm{nm}$ のシナプス間隙 で行われる化学物質の放出や， nM レベルの化学物質 の計測には，空間分解能と時間分解能が求められる. その実現には，従来の延長ではなく，新しい原理を計 測に加えていく必要がある，特に，化学物質を酸化・ 還元電流でとらえることに関しては，微小電流計測器 の改良のみではなく，ISFET や高速 CVなどの計測要 素を取り入れていく必要がある。今後は，技術の改良 と共に神経伝達物質の放出サイトのマッピングを行ら 予定である.

\section{謝 辞}

本研究は, 末永智一教授 (東北大学), Yuri Korchev 教授（インペリアルカレッジロンドン）とその研究室 のメンバーとの共同で行われた.

文 献

1) Matsue, T. et al. (1994) J. Phys. Chem. 98, 11001-11003. DOI: $10.1021 / \mathrm{j} 100094 \mathrm{a} 002$.

2) Shiku, H. et al. (2001) Anal. Chem. 73, 3751-3758. DOI: 10.1021/ ac010339j.

3) Shevchuk, A. I. et al. (2006) Angew. Chem. Int. Ed. 45, 2212-2216. DOI: $10.1002 /$ anie. 200503915 .

4) Novak, P. et al. (2009) Nat. Methods 6, 279-281. DOI: 10.1038/ nmeth.1306

5) Korchev, Y. E. et al. (2000) Nat. Cell Biol. 2, 616-619. DOI: $10.1038 / 35023563$.

6) Gorelik, J. et al. (2002) Proc. Natl. Acad. Sci. USA 99, 16018 16023. DOI: $10.1073 /$ pnas. 252458399 .

7) Novak, P. et al. (2014) Nano Lett. 14, 1202-1207. DOI: 10.1021/ nl404068p.

8) Takahashi, Y. et al. (2010) J. Am. Chem. Soc. 132, 10118-10126. DOI: $10.1021 / \mathrm{ja} 1029478$.

9) Takahashi, Y. et al. (2011) Angew. Chem. Int. Ed. 50, 9638-9642. DOI: $10.1002 /$ anie.201102796.

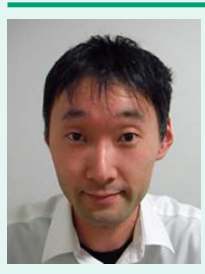

高橋康史（たかはし やすふみ）

金沢大学理工研究域准教授

2009年東北大学大学院環境科学研究科博士課程修

了, 博士 (学術), JSPS 海外特別研究員, 東北大学 原子分子材料高等研究機構助手, 助教を経て現職. 研究内容:電気化学計測

高橋康史 連絡先: ₹ 920-1192 石川県金沢市角間町自然科 学研究科 2 号館 $2 A 316$ 号室

E-mail: yasufumi@se.kanazawa-u.ac.jp URL: http://fukuma.w3.kanazawa-u.ac.jp/frame html 